\title{
The effect of different feeding schedules on egg quality, blood, and bone parameters in broiler breeders
}

\author{
A. Londero ${ }^{1,3}$, A.P. Rosa ${ }^{1}$, C.E.B. Vivas ${ }^{1}$, C. Orso ${ }^{1}$, M.O. Fernandes ${ }^{1}$, S.J. Paixão ${ }^{1}$, C.B.S. Giacomini ${ }^{1}$, \\ C.M. Andrade ${ }^{2}$, H.E. Palma ${ }^{2}$ \\ ${ }^{1}$ Poultry Science Laboratory, Department of Animal Science, Federal University of Santa Maria, RS, Brazil. \\ ${ }^{2}$ Clinic Veterinary Laboratory, Department of Small Animal Clinic, Federal University of Santa Maria, RS, Brazil.
}

\begin{abstract}
The aim of this study was to evaluate different feeding schedules and their relationship to calcium $(\mathrm{Ca})$ and phosphorus (P) plasma levels and egg quality of broiler breeders. The feeding schedules were: single feeding at 8:00 AM; twice daily feeding (50\% at 8:00 AM and 50\% at 3:00 PM) and single feeding at 3:00 PM. 330 female and 45 male Cobb 500 broiler breeders were used from 40 to 60 weeks of age. The experimental design was completely randomized, consisting of 3 treatments with 5 replicates each, with 22 females and 3 males. The nutritional requirements were according to guideline recommendations. The following parameters were assessed weekly: total egg production, egg specific gravity, egg and eggshell weight, and eggshell thickness. Ca and P plasma levels, tibia weight and its length and Seedor index were evaluated at the end of the study. To determine the effect of feeding schedules, the total calcium and phosphorus plasma at oviposition time and $21 \mathrm{~h}$ after oviposition was evaluated. At 60 weeks of age, tibias were taken from the right leg, dried, measured and weighted. There were no differences among treatments regarding egg production, tibia length and Seedor index. Hens fed at 8:00 AM showed higher tibia weight than hens fed twice daily. Broiler breeders fed at 3:00 PM had higher egg $(\mathrm{P}=0.0105)$ and shell $(\mathrm{P}=0.0066)$ weight than others, and hens fed at 3:00 PM had more specific gravity $(P=0.0219)$ and eggshell thickness $(P=0.0419)$ than hens fed at 8:00 AM. $\mathrm{Ca}(\mathrm{P}=0.758)$ and $\mathrm{P}(\mathrm{P}=0.811)$ plasma levels were higher in hens fed at 8:00 AM than hens fed at 3:00 PM after $21 \mathrm{~h}$ of oviposition. Broiler breeders fed at 3:00 PM had better egg quality without any change in production, as well as these hens showing higher available $\mathrm{Ca}$ and $\mathrm{P}$ plasma levels.
\end{abstract}

Keywords: bone, calcium, egg production, eggshell, phosphorus.

\section{Introduction}

Broiler breeders are continuously selected for weight gain. To regulate this gain, limit health risks, and also maintain high fertility, husbandry practices for the parent stock of broiler chickens encompass a high degree of feed restriction (Renema and Robinson,
2004). Quantitative feed restriction is a common management technique used to increase the reproductive efficiency of broiler breeder hens (Moradi et al., 2013).

A restriction of feed intake to approximately 50 to $60 \%$ of ad libitum intake is a practical approach to reduce metabolic disorders and improve egg production in broiler breeder hens (Chen et al., 2006). Feed restriction is typically performed as once a day feeding during the laying period. This feed is rapidly consumed (about $4 \mathrm{~h}$ ); therefore, the hens fast for a long time before their next feeding (Spradley et al., 2008). The practice of feeding only once a day cannot supply the nutritional needs of hens, particularly for eggshell formation (Bootwalla et al., 1983), which normally starts in the afternoon or evening. This is because broiler breeders are unable to retain calcium from the crop to the lower digestive tract at a uniform rate (Farmer et al., 1983a). It may be possible to improve eggshell quality if nutrients are supplied at times that correspond more closely to periods of eggshell deposition by changing the time of feed intake (Backhouse and Gous, 2005).

Calcium is one of the major elements required for maintenance and egg production in hens. The hen will obtain the required calcium from the diet via the intestine and also from medullary bone reserves (Halls, 2005). The probable course for $\mathrm{Ca}$ ingested by hens in the morning would be the small intestine-blood-gland of eggshell and then the eggshell. Therefore, hens with a scheduled feeding in the afternoon until the early calcifications of eggshell can deposit the Ca directly into the egg (Calderon, 1994).

On the other hand, medullary bone is found in sexually mature and egg producing hens. It is the primary bone calcium reserve for eggshell formation. Medullary bone calcium can be deposited and released in response to changes in calcium supply and demand during eggshell formation. Intestinal calcium absorption reaches over $70 \%$ when the shell gland is actively forming the shell. An average of $4 \mathrm{~g}$ of calcium is required in the diet to maintain good shell quality since only $50-60 \%$ of dietary calcium is actually used in the shell formation (Halls, 2005). Phosphorus is another main component in eggshell formation. Eggshells contain very little phosphorus, but this mineral interacts with calcium during bone formation. The calcium bone 
reserves are replenished during the time when the shell gland is in the inactive state (Halls, 2005). According to McCormack et al. (2001), feed restriction in broiler breeders results in changes in the relative growth of different body components, but there is little information on the impact of this on bone structure and composition.

The metabolic and structural function of these minerals in bone and eggshell formation are essential to poultry production. Thus, feeding at a later time or twice a day can retain them within the gut of the hen and provide a longer acting source of calcium, which can reduce the need for calcium resorption from the medullary bones. Therefore, the aim of this study was to evaluate the effect of different feeding schedules in broiler breeders on egg quality, $\mathrm{Ca}$ and $\mathrm{P}$ plasma levels and bone parameters.

\section{Materials and Methods}

This experiment was carried out in the Poultry Science Laboratory (LAVIC) of the Federal University of Santa Maria (UFSM). This study was based on compliance with the Welfare Standards and was approved by the Ethics Committee of UFSM. 330 broiler breeder hens and 45 roosters were used in the trial. They were placed in an open-sided house with a wood shaving floor. The broiler breeders were reared following the Cobb 500 broiler breeder according to nutritional recommendations (Rostagno et al., 2011). From 28 to 40 weeks of age, the three groups were fed at different schedules and the performance was evaluated. The selected hens were placed in 15 pens, each pen had $4.615 \mathrm{~m}^{2}(3.24 \mathrm{x} 1.42 \mathrm{~m})$ and was equipped with an automatic drinker, one tube feeder for the breeder hens, and a trough-type feeder for the roosters. Hens were fed with corn-soybean-based mash diets (Table 1). The feed supply was strictly controlled, in accordance to the recommendations of the breeder company. Water was ad libitum and 16:30h light/day photoperiod was applied, with artificial lighting complementing natural lighting.

Table 1. Diet composition and nutritional levels used ${ }^{1}$.

\begin{tabular}{|c|c|}
\hline Ingredients & $(\%)$ \\
\hline Corn & 69.06 \\
\hline Soybean meal $46 \%$ & 21.15 \\
\hline Soybean oil & - \\
\hline Dicalcium Phosphate & 1.60 \\
\hline Limestone $38 \% \mathrm{Ca}$ & 6.99 \\
\hline Salt & 0.40 \\
\hline Premix $^{1}$ & 0.50 \\
\hline DL-Methionine $99 \%$ & 0.08 \\
\hline \multicolumn{2}{|l|}{ Calculated Nutritional Composition } \\
\hline Crude Protein $(\%)$ & 15.50 \\
\hline Metabolizable Energy (kcal/kg) & 2800 \\
\hline Calcium $(\%)$ & 3.20 \\
\hline Available Phosphorus (\%) & 0.39 \\
\hline
\end{tabular}

\section{Treatments}

The hens were distributed in three experimental groups with similar body weight and uniformity (average of $3.62 \mathrm{~kg}$ and uniformity of $90 \%$ ). The hens were acquired from a commercial poultry company to be used in the trial ( 22 weeks old) and they were submitted to different treatments from 28 weeks of age. The hens were fed with the same basal diet (corn and soybean) from 22 to 60 weeks of age. Each one of experimental treatments was randomly assigned in 5 replicates, each one with 22 hens and 3 roosters per pen. Three feeding schedules were tested: a single feeding at 8:00 AM, twice daily feeding (50\% at 8:00 $\mathrm{AM}$ and $50 \%$ at 3:00 PM), and a single feeding at 3:00 PM. From 40 to 60 weeks of age, the hens' performance was evaluated.

\section{Experimental responses measured}

The egg production per hen housed was calculated weekly. The egg production was determined by the mathematical relationship of number of laid eggs, hens, and production days multiplied by 100 . Laying rate was determined by 6 daily collections over the experimental period. Fifteen eggs/treatment ( 5 replicates of 3 eggs each) were used to determine egg weight, eggshell weight and eggshell thickness. The egg specific gravity was determined through the immersion of the eggs in saline solutions with densities of 1070, 1075, 1080, 1085, 1090, 1095, and $1100 \mathrm{~g} / \mathrm{cm}^{3}$ using Archimede's principle as described by Peebles and McDaniel (2004). Egg weight and eggshell weight were determined through a precision scale $(0.001 \mathrm{~g})$. The 
eggshell was weighted after being dried in ambient temperature for 3 days (Rodriguez-Navarro et al., 2002). Shell thickness was measured with the Electronic Outside Micrometer $0.001 \mathrm{~mm}$ at three equatorial points on each egg (Lin et al., 2004).

\section{Analysis of calcium and phosphorus level in blood}

At 55 weeks of age, blood samples were collected from 3 hens per replicate immediately after oviposition time $(0 \mathrm{~h})$. The hens were marked with dye and $21 \mathrm{~h}$ after oviposition, blood samples were collected once again (Miles et al., 1984; Junqueira et al., 2002). Blood samples from each treatment were placed in tubes and packed in ice. Subsequently, they were centrifuged at $3000 \mathrm{rpm}$ for a period of time up to $15 \mathrm{~min}$ to separate the plasma. The $\mathrm{Ca}$ and $\mathrm{P}$ measurements of the samples were analyzed by the Clinical Laboratory Veterinary (LACVET/UFSM), in Santa Maria (RS), Brazil.

\section{Analysis of bone quality}

At 60 weeks of age, 3 hens per pen were used to the evaluate the right tibia. The tibia was cooked, the fibula and adherent tissues were removed and dried, and after this, their length, weight, and Seedor index were measured. Tibia weight was determined through a precision scale $(0.001 \mathrm{~g})$. Bone density was measured by the Seedor index $(\mathrm{mg} / \mathrm{mm})$ and obtained by the value of weight $(\mathrm{mg})$ and the length $(\mathrm{mm})$ of the bone assessed (Seedor, 1993).

\section{Experimental design and statistical analysis}

The experimental design was completely randomized, with three treatments (a single feeding at 8:00 AM, twice daily feeding (50\% at 8:00 AM and 50\% at 3:00 PM), and a single feeding at 3:00 PM) with 5 replicates each. All the data were subject to Analysis of Variance. When significant differences were observed at $10 \%$ in the variance average, the Turkey test was applied for comparison among treatments. Statistical procedures were performed using the SAS software, 2013.

\section{Results}

In the egg production, only in the 44 weeks of age group did production decrease significantly $(\mathrm{P}=0.0319)$ when the hens were fed at 3:00 PM compared to hens fed 8:00 AM (Table 2). The egg specific gravity $(\mathrm{P}=0.0219)$ and eggshell thickness $(\mathrm{P}=0.0419)$ were significantly higher in hens fed at 3:00 PM than the broilers breeder fed once in the morning. Hens fed at 3:00 PM produced egg $(\mathrm{P}=0.0105)$ and eggshells $(\mathrm{P}=0.0066)$ that were heavier than the other groups (Table 3). The $\mathrm{Ca}$ and $\mathrm{P}$ plasma levels were not affected by feeding schedules used at the time of oviposition $(0 \mathrm{~h})$, but at $21 \mathrm{~h}$ after oviposition, the hens fed at 3:00 PM showed higher levels than hens fed at 8:00 AM (Table 4). Hens fed at 8:00 AM had higher tibia weight than hens fed at 8:00 AM and 3:00 PM. The feeding schedules used in broiler breeders did not affect the tibia length and Seedor index (Table 4).

Table 2. Laying rate of broiler breeders submitted to the different treatments ${ }^{1}$.

\begin{tabular}{|c|c|c|c|c|c|}
\hline \multirow{2}{*}{$\begin{array}{l}\text { Breeder age } \\
\text { (weeks) }\end{array}$} & \multicolumn{5}{|c|}{ Feeding time $(\mathrm{h})$} \\
\hline & 8:00 AM & 8:00 AM and 3:00 PM & 3:00 PM & SEM* & $\mathrm{P}$ values \\
\hline & \multicolumn{5}{|c|}{ Egg production (\%) } \\
\hline 40 & 77.14 & 73.85 & 73.73 & 5.13 & 0.5119 \\
\hline 41 & 77.08 & 74.21 & 73.36 & 5.00 & 0.4893 \\
\hline 42 & 79.09 & 72.08 & 73.24 & 6.21 & 0.2027 \\
\hline 43 & 77.46 & 76.49 & 71.81 & 4.42 & 0.1396 \\
\hline 44 & $76.23^{\mathrm{a}}$ & $75.71 \mathrm{ab}$ & $71.54^{\mathrm{b}}$ & 2.66 & 0.0319 \\
\hline 45 & 74.15 & 69.74 & 69.74 & 3.82 & 0.1518 \\
\hline 46 & 72.08 & 70.77 & 68.70 & 3.94 & 0.4198 \\
\hline 47 & 74.28 & 72.07 & 71.81 & 4.72 & 0.6719 \\
\hline 48 & 69.97 & 73.24 & 68.05 & 4.20 & 0.1853 \\
\hline 49 & 70.13 & 70.26 & 64.82 & 5.69 & 0.2659 \\
\hline 50 & 70.00 & 70.78 & 66.75 & 2.89 & 0.1053 \\
\hline 51 & 66.10 & 69.74 & 66.10 & 4.33 & 0.3428 \\
\hline 52 & 67.40 & 69.35 & 65.19 & 3.41 & 0.1992 \\
\hline 53 & 67.27 & 69.35 & 64.80 & 4.35 & 0.2916 \\
\hline 54 & 65.32 & 67.53 & 63.77 & 3.26 & 0.2282 \\
\hline 55 & 63.11 & 64.80 & 60.52 & 3.98 & 0.2693 \\
\hline 56 & 62.34 & 65.71 & 63.24 & 4.50 & 0.4928 \\
\hline 57 & 62.73 & 63.22 & 61.17 & 3.95 & 0.6995 \\
\hline 58 & 60.00 & 61.67 & 60.65 & 5.04 & 0.8716 \\
\hline 59 & 58.96 & 64.12 & 58.31 & 4.48 & 0.1215 \\
\hline 60 & 58.05 & 57.84 & 57.18 & 4.29 & 0.9463 \\
\hline Average (40-60 weeks) & 68.99 & 68.95 & 66.25 & 2.63 & 0.2112 \\
\hline
\end{tabular}


Londero et al. Feeding schedules in broiler breeders.

Table 3. Specific gravity (SG), egg weight (EW), eggshell weight (SW) and eggshell thickness (ET) evaluated in broiler breeder hens from 40 to 60 weeks of age ${ }^{1}$.

\begin{tabular}{lccccc}
\hline & \multicolumn{3}{c}{ Feeding time $(\mathrm{h})$} \\
\cline { 2 - 6 } & $8: 00 \mathrm{AM}$ & $8: 00$ AM and 3:00 PM & $3: 00 \mathrm{PM}$ & SEM $^{*}$ & P values \\
\hline SG $\left(\mathrm{g} / \mathrm{cm}^{3}\right)$ & $1084.36^{\mathrm{b}}$ & $1084.89^{\mathrm{ab}}$ & $1085.93^{\mathrm{a}}$ & 0.77 & 0.0219 \\
EW $(\mathrm{g})$ & $72.17^{\mathrm{b}}$ & $71.98^{\mathrm{b}}$ & $73.63^{\mathrm{a}}$ & 0.77 & 0.0105 \\
SW $(\mathrm{g})$ & $6.70^{\mathrm{b}}$ & $6.72^{\mathrm{b}}$ & $7.00^{\mathrm{a}}$ & 0.13 & 0.0066 \\
ET $(\mathrm{mm})$ & $0.435^{\mathrm{b}}$ & $0.437^{\mathrm{ab}}$ & $0.445^{\mathrm{a}}$ & 0.00 & 0.0419 \\
\hline
\end{tabular}

${ }^{\mathrm{T}}$ Data represent means from 5 replicates (i.e., pens) per treatment. ${ }^{\mathrm{a}, \mathrm{b}}$ Means within a row, not sharing a common superscript, are significantly different $(\mathrm{P} \leq 0.05)$. *Pooled SEM, $\mathrm{n}=5$.

Table 4. Calcium and phosphorus in plasma at the time of egg laying ( 0 hours) and 21 hours after laying ${ }^{1}$

\begin{tabular}{lccccc}
\hline Treatments & $8: 00 \mathrm{am}$ & $8: 00 \mathrm{am}$ and 3:00 pm & $3: 00 \mathrm{pm}$ & SEM* & P values \\
\hline & \multicolumn{5}{c}{0 hours } \\
\cline { 2 - 7 } Calcium (mg/dl) & 23.24 & 27.1 & 28,32 & 4.60 & 0.2307 \\
Phosphorus (mg/dl) & 6.3 & 7.12 & 6.73 & 1.09 & 0.5097 \\
\hline & \multicolumn{7}{c}{21 hours } \\
Calcium (mg/dl) & $23.35^{\mathrm{b}}$ & $27.04^{\mathrm{ab}}$ & $28,12^{\mathrm{a}}$ & 3.11 & 0.0758 \\
Phosphorus (mg/dl) & $4.93^{\mathrm{b}}$ & $6.17^{\mathrm{ab}}$ & $6.79^{\mathrm{a}}$ & 1.19 & 0.0811 \\
\hline
\end{tabular}

Data represent means from 5 replicates (i.e., pens) per treatment. ${ }^{\mathrm{a}, \mathrm{b}}$ Means within a row, not sharing a common superscript, are significantly different $(\mathrm{P} \leq 0.05)$. *Pooled SEM, $\mathrm{n}=5$.

\section{Discussion}

The total egg production and the weekly egg production are shown in Table 2. The total egg production in the experimental period was not affected. At 44 weeks of age, the hens fed once at 8:00 AM had better egg production than hens fed once at 3:00 PM $(\mathrm{P}=0.0319)$. However, in the other weeks evaluated, the different schedule feeding did not influence egg production. In the same way, Avila et al. (2003a) did not observe a difference in the total egg production through 66 weeks of age between broiler breeders fed once or twice a day. Moreover, the egg production results were reported by Harms (1991), which changed the time of feeding in broiler breeder hens from 8:00 AM to 4:00 PM, verifying a significant reduction in their egg production. Broiler breeder hens fed once a day in the afternoon had more egg production than those fed once a day in the morning (Farmer et al., 1983a; Brake and Peebles, 1986; Wilson and Keeling, 1991).

Spradley et al. (2008) reported that broiler breeders fed twice a day laid more and heavier eggs through 42 weeks of age than those fed once a day. They believed that increased egg weight was related to providing feed later in the day (3:00 PM). Moradi et al. (2013) evaluated hens fed once a day at 6:15 AM and a twice a day feeding (at 6:15 AM and 12:15 PM) and Taherkhani et al. (2010) evaluated hens fed once a day at 7:30 AM and twice a day feeding (at 7:30 AM and 11:30 AM), both authors reported that broiler breeders fed twice a day laid more and heavier eggs than those fed once a day. The influence of increasing feeding frequency may be related to a reduction in the fasting period during the day-light cycle (Moradi et al., 2013). The results of this study were according to the results reported by Cave (1981), Bootwalla et al. (1983) and Samara et al. (1996), who reported that different feeding schedules had no effect on egg production. Backhouse and Gous (2005) evaluated different feeding schedules for broiler breeders (57 week old), at 07:30 AM, 10:00 AM, 1:00 PM and 3:30 PM and other treatments, in which hens were daily half fed at 07:30 AM and at 3:30 PM (half-feeding) and it was observed that feeding time had no significant effect on total egg production from 26 to 32 weeks of age.

The provision of a limited daily allowance of feed in the morning may not supply the nutrients to coincide with the broiler breeder hen's needs (Cave, 1981). This is particularly important with $\mathrm{Ca}$, because it is an essential component of eggshell formation. It normally begins in the afternoon or evening, and the utilization of dietary $\mathrm{Ca}$ in morning-fed broiler breeders is poor due to the inability of these hens to maintain $\mathrm{Ca}$ from the crop to the lower digestive tract at a uniform rate (Farmer et al., 1983a). Feeding broiler breeders later in the day supplies dietary $\mathrm{Ca}$ at times that correspond more closely to periods of shell deposition (Farmer et al., 1983a), resulting in a better Ca utilization (Farmer et al. 1983b; Roland and Farmer, 1984), which is usually manifested as an increase in egg specific gravity, eggshell weight and shell thickness (Backhouse and Gous, 2006). In this study, the highest egg specific gravity was observed in hens fed at 3:00 PM (Table 3). Backhouse and Gous (2005) showed that split feeding could improve the eggshell quality. Harms (1991) also observed that egg specific gravity is increased when the broiler breeder hens were fed daily at 4:00 PM, the improvement was very small compared with the result at 8:00 AM.

The egg weight increase observed in this study is in agreement with the study by Cave (1981), which 
described that egg weight was better for hens fed two or three times per day than hens fed once a day (Table 3). Spradley et al. (2008) compared hens that received once-a-day feeding treatment at 6:30 AM, whereas the hens under the twice-a-day feeding treatment received $60 \%$ of their total daily feed allotment at $06: 30 \mathrm{AM}$ and $40 \%$ at 3:00 PM, and they concluded that the average egg weight for the entire egg production period was better in hens fed twice a day than once-a-day. Moreover, Samara et al. (1996) and Harms (1991) reported that egg weight was not affected by feeding time. In addition, Backhouse and Gous (2005) report that egg weight was not significantly affected by the feeding time, suggesting that differences in shell thickness and oviposition times were not due to increased oviducal transit times.

The weight of eggshells was significantly higher in hens fed at 3:00 PM than broiler breeders fed once in the morning or twice a day. Lewis and Perry (1988) reported an increase in eggshell thickness and eggshell weight when broiler breeders were given half the daily feed allocation twice daily compared to a single allocation of feed provided in the morning. In this study, the eggshell thickness was significantly higher in hens fed once in the afternoon than broiler breeders fed once in the morning. Thus, the delayed feeding improved shell thickness by allowing more $\mathrm{Ca}$ to bypass the bone and depositing Ca directly on the egg via blood (Roland and Farmer, 1984).

Feinberg et al. (1937) was a pioneer in registering a slight fluctuation in $\mathrm{Ca}$ and marked fluctuation of serum $\mathrm{P}$ during the egg formation. Likewise, Miller et al. (1977) also observed cyclical variation blood phosphorus in the laying hen, with the lowest $\mathrm{P}$ level about $2 \mathrm{~h}$ before oviposition, remaining constant up to $4 \mathrm{~h}$ after oviposition. The average values were $5.29 \mathrm{mg} / \mathrm{dl}$, and then kept increasing, reaching a peak 21-22 $\mathrm{h}$ after oviposition, corresponding with the active period of eggshell formation and bone demineralization. Taylor and Stringer (1965) have suggested that the period where the phosphorus plasma level is minimum represents the process pause of the eggshell formation, the return of the $\mathrm{P}$ to the bone and the kidney filtration of the element.

Mongin and Sauveur (1979) confirmed the cyclical nature of the phosphorus plasma, reporting that the phosphorus declining of hens, $10 \mathrm{~h}$ after the oviposition, is due solely to eggshell formation and it is independent of the light program that is imposed on them or the amount of feed ingested. The blood $\mathrm{P}$ values found by the authors were minimal during oviposition, continuing up to $10 \mathrm{~h}$ after the oviposition. Then, an increase was observed reaching a peak of 18 to $20 \mathrm{~h}$ following oviposition and returning to normal levels before the next oviposition (Junqueira et al. 2002).

In this study, different feeding schedules (8:00 $\mathrm{AM}$, 8:00 AM and 3:00 PM, and 3:00 PM) did not affect $\mathrm{P}$ levels at the time of oviposition $(0 \mathrm{~h})(6.3,7.12$,
$6.73 \mathrm{mg} / \mathrm{dl}$ ). But after $21 \mathrm{~h}$ of oviposition, there was a difference among the feeding schedules on $\mathrm{P}$ levels (4.93, 6.17, $6.79 \mathrm{mg} / \mathrm{dl} ; \mathrm{P}=0.0811$; Table 4. Miles et al. (1984), after performing experiments, reported that the average of $\mathrm{P}$ content in plasma at the time of oviposition for hens fed in the morning or afternoon was 3.95 and $4.10 \mathrm{mg} / \mathrm{dl}$, respectively. On the other hand, higher values from 4.91 to $5.90 \mathrm{mg} / \mathrm{dl}$ were obtained from the plasma of hens which blood was collected $21 \mathrm{~h}$ after oviposition. In relation to the plasmatic calcium, it was observed that there was no fluctuation at the time of oviposition $(0 \mathrm{~h}$; $23.24,27.1,28.32 \mathrm{mg} / \mathrm{dl}$ ), along the process of egg formation, when the hens were fed at different times. But, after $21 \mathrm{~h}$ of oviposition, there was difference among the feeding schedules on $\mathrm{Ca}$ levels $(23.35,27.04,28.12$ $\mathrm{mg} / \mathrm{dl} ; \mathrm{P}=0.0758)$. Junqueira et al. (2002), evaluating hen feed restriction, reports a small increase in plasmatic calcium levels $21 \mathrm{~h}$ after oviposition and this increase can be related to the fact that there is less $\mathrm{Ca}$ elimination through the renal tract, or also, because there is an increase in the mobilization of the bones, as an attempt to maintain normal levels in the hen.

Calcium metabolism in laying hens is dominated by the uterus for shell formation. As a result, inadequate $\mathrm{Ca}$ in diet leads to disruption of ovulation and cessation of lay until their meager Ca reserves are replenished. Under normal conditions, when a high $\mathrm{Ca}$ diet is being applied, the medullary bone is resorbed when supplies of $\mathrm{Ca}$ from the gut are not sufficient to provide it for the shell gland demands. This occurs in the early morning hours, when most of the previous day's feeding has been absorbed (Taylor and Dacke, 1984). It is suggested that reabsorption of medullary bone is induced by an increase in the circulating concentration of the parathyroid hormone $(\mathrm{PTH})$ secretion, which is stimulated by the decline in $\mathrm{Ca}_{2}+$ concentration that occurs during shell formation (Taylor and Dacke, 1984).

No treatment effect was observed on the tibia length, but the tibia weight was higher in hens fed at 8:00 $\mathrm{AM}$ than hens fed 8:00 AM and 3:00 PM $(\mathrm{P}=0.0697)$. However Ávila et al. (2003b) evaluated different feeding schedules for broiler breeders: 06:30 AM, 50\% feeding at $06: 30 \mathrm{AM}$ and $50 \%$ feeding at $3: 30 \mathrm{PM}$, 11:30 AM, or 3:30 PM, and reported that there was an effect of treatment for tibia weight of hens fed at 11:00 AM compared to those with other feeding schedules, and related this result to the low mobilization of $\mathrm{Ca}$ and $\mathrm{P}$ to the plasma required for eggshell synthesis. Bootwalla et al. (1989) fed female broiler breeders in different periods of the day and found that $\mathrm{Ca}$ and $\mathrm{P}$ plasma levels were influenced by feeding, stage of egg formation, and the moment of oviposition. In this study, bone quality measured by the Seedor index was not affected (Table 5).

In conclusion, the present study suggests that the breeding of broilers submitted to different feeding times (40 to 60 weeks of age) showed no difference in 
Londero et al. Feeding schedules in broiler breeders.

the egg production. Hens fed once in the afternoon had better egg specific gravity and eggshell thickness than hens fed once in the morning. Hens fed later showed better egg weight and eggshell than others. $\mathrm{Ca}$ and $\mathrm{P}$ levels were higher in hens fed at 8:00 AM than hens fed at 3:00 PM after $21 \mathrm{~h}$ of oviposition. The tibia weight was higher in hens fed at 8:00 AM than hens fed at 8:00 $\mathrm{AM}$ and 3:00 PM.

Table 5. Effect of time of feeding on bone quality in broiler breeder hens from 40 to 60 weeks of age ${ }^{1}$.

\begin{tabular}{lccccc}
\hline & \multicolumn{5}{c}{ Feeding time $(\mathrm{h})$} \\
\cline { 2 - 6 } & $8: 00 \mathrm{AM}$ & $8: 00$ AM and 3:00 PM & $3: 00 \mathrm{PM}$ & SEM $^{*}$ & P values \\
\hline Weight $(\mathrm{mg})$ & $15999^{\mathrm{a}}$ & $15061^{\mathrm{b}}$ & $15210^{\mathrm{ab}}$ & 615.56 & 0.0697 \\
Length $(\mathrm{mm})$ & 121.10 & 120.30 & 118.50 & 1.86 & 0.1260 \\
Seedor index $(\mathrm{mg} / \mathrm{mm})$ & 132.23 & 125.15 & 128.40 & 5.17 & 0.1378 \\
\hline
\end{tabular}

${ }^{1}$ Data represent means from 5 replicates (i.e., pens) per treatment. ${ }^{a, b}$ Means within a row, not sharing a common superscript, are significantly different $(\mathrm{P} \leq 0.05)$. *Pooled SEM, $\mathrm{n}=5$.

\section{Acknowledgments}

The location offered by UFSM.

\section{References}

Avila VS, Penz Jr AM, Brum PAR, Rosa PS, Guidoni AL, Figueiredo ÉAP. 2003a. Performance of female broiler breeders submitted to different feeding schedules. Braz J Poult Sci, 5:197-201.

Avila VS, Penz Jr AM, Rosa PS, Brum PAR, Guidoni AL, Ledur MC. 2003b. Influence of feeding time on sexual maturity and carcass composition in female broiler breeders. Braz J Poult Sci, 5:189-196.

Backhouse D, Gous R.M. 2005.The effect of feeding time on shell quality and oviposition time in broiler breeders. Br Poult Sci, 46:255-259.

Backhouse D, Gous RM. 2006. Responses of adult broiler breeders to feeding time. World's Poult Sci, J, 62:269-281.

Bootwalla SM, Wilson HR, Harms RH. 1983. Performance of broiler breeders on different feeding systems. Poult Sci, 62:2321-2325.

Bootwalla SM, Wilson HR, Harms RH. 1989. Plasma calcium and phosphorus levels of broiler breeders with different feeding schedules. Poult Sci, 39:391-398.

Brake J, Peebles ED. 1986. Effect of strain and time of day of feeding on reproductive performance and shell quality of broiler breeders. Poult Sci, 65:156.

Calderon C. 1994. Efectos nutricionales sobre la calidad de la cáscara. In: Conferência APINCO 1994 de Ciência e Tecnologia Avícolas, 1994, Santos, SP. Santos, SP: FACTA. pp. 35-66.

Cave NA. 1981. Effect of diurnal programs of nutrient intake on the performance of broiler breeder hens. Poult Sci, 60:287-1292.

Chen SE, McMurtry JP, Walzem RL. 2006. Overfeeding-induced ovarian dysfunction in broiler breeder hens is associated with lipotoxicity. Poult Sci, 85:70-81.

Farmer M, Roland DA Sr, Brake J, Eckman MK. 1983a. Calcium metabolism in broiler breeder hens. 1. Calcium status of the digestive tract of broiler breeders throughout a 24 hour period. Poult Sci, 62:459-464.
Farmer M, Roland DA Sr, Eckman MK. 1983b. Calcium metabolism in broiler breeder hens. 2. The influence of the time of feeding on calcium status of the digestive system and egg shell quality in broiler breeders. Poult Sci, 62:465-471.

Feinberg ,JG, Hughes JS, Scott HM. 1937. Fluctuations of calcium and inorganic phosphorus in the blood of the laying hen during the cycle of on egg. Poult Sci, 16:132-134.

Halls A. Egg formation and eggshell quality in layers. 2005. Nutrifax, Nutrition News and Information Update. Avaliable: http://www.nutrecocanada.com/docs/shurgain---poultry/egg-formation-and-eggshell-qualityin-layers.pdf. Accessed on: Febr 20th, 2015.

Harms RH. 1991. The influence of changing time of feeding on performance of broiler breeder hens. Poult Sci, 70:1695-1698.

Junqueira OM, Andreotti1 MO, Rodrigues EA, Faria DE, Casartelli EM. 2002. Influência da restrição alimentar sobre alguns constituintes plasmáticos e qualidade da casca dos ovos de poedeiras comerciais. Acta Sci Maringá, 24:1021-1025.

Lewis PD, Perry GC. 1988. Effect of a single or double daily allocation of food on shell weight and oviposition time of broiler breeder hens. In: Proceedings of the Fourth International Poultry Breeders Conference, 1988, Ayr, Scotland. Ayr: The West of Scotland College. pp. 72-78.

Lin H, Mertens K, Kemps B, Govaerts T, De Ketelaere B, De Baerdemaeker J, Decuypere E, Buyse J. 2004. New approach of testing the effect of heat stress on eggshell quality: mechanical and material properties of eggshell and membrane. Br Poult Sci, 45:476-482.

McCormack HA, Fleming R, McTeir L, Whitehead CC. 2001. Bone development up to 6 weeks of age in feed-restricted broiler breeders fed on diets supplemented with different concentrations of ascorbic acid. Br Poult Sci, 42(suppl):91-92.

Miles RD, Junqueira OM, Harms RH. 1984. Plasma phosphorus at 0,6 , and 21 hours postoviposition in hens laying in the morning or afternoon. Poult Sci, 63:354359.

Miller ER, Harms RH, Wilson HR. 1977. Cyclic 
changes in serum phosphorus of laying hens. Poult Sci, 56:586-589.

Mongin P, Sauveur B. 1979. Plasma inogarnic phosphorus concentration during egg-shell formation. Effect of the physical form of the dietary calcium. $\mathrm{Br}$ Poult Sci, 20:401-412.

Moradi S, Zaghari M, Shivazad M, Osfoori R, Mardi M. 2013. The effect of increasing feeding frequency on performance, plasma hormones and metabolites, and hepatic lipid metabolism of broiler breeder hens. Poult Sci, 92:1227-1237.

Peebles ED, McDaniel CD.. 2004. A Practical Manual for Understanding the Shell Structure of Broiler Hatching Eggs and Measurements of their Quality. Mississippi State, MS: Mississippi Agricultural and Forestry Experimental Station,16 pp. (Bulletin 1139).

Renema RA, Robinson FE.. 2004. Defining normal: comparison of feed restriction and full feeding of female broiler breeders. World's Poult Sci J, 60:508-522.

Rodriguez-Navarro A, Kalin O, Nys Y, Garcia-Ruiz JM. 2002. Influence of the microstructure on the shell strength of eggs laid by hens of different ages. Br Poult Sci, 43:395-403.

Roland DA Sr, Farmer M. 1984. Egg shell quality II: importance of time of calcium intake with emphasis on broiler breeders. World's Poult Sci J, 40:255-260.

Rostagno HS, Albino LFT, Donzele JL. 2011. Tabelas Brasileiras para Aves e Suínos: composição de alimentos e exigências nutricionais. 3.ed. Viçosa, MG: Universidade Federal de Viçosa. 252 pp.

Samara MH, Robbins KR, Smith MO. 1996. Interaction of feeding time and temperature and their relationship to performance of the broiler breeder hen. Poult Sci, 75:34-41.

Seedor JG. 1993. The biophosphanate alendronate (MK-217) inhibit bone loss due to ovariectomy in rats. $J$ Bone Miner Res, 4:265-270.

Spradley J M, Freeman M E, Wilson J L, Davis A J. 2008. The influence of a twice-a-day feeding regimen after photostimulation on the reproductive performance of broiler breeder hens. Poult Sci, 87:561-568.

Taherkhani R, Zaghari M, Shivazad M, Zare Shahneh A. 2010 A twice-a-day feeding regimen optimizes performance in broiler breeder hens. Poult Sci, 89:169-1702.

Taylor TG, Stringer DA. 1965. Eggshell formation and skeletal metabolism. In: Sturke PD (Ed.). Avian Physiology. New York: Cornell University Press. pp. 485-514.

Taylor TG, Dacke CG. 1984. Calcium metabolism and its regulation. In: Freeman BM (Ed.). Physiology and Biochemistry of the Domestic Fowl. London, UK: Academic Press,. vol. 5, pp. 127-164.

Wilson HR, Keeling LJ. 1991. Effect of time of feeding on oviposition time and production parameters in broiler breeders. Poult Sci, 70:254-259. 